https://helda.helsinki.fi

Skin abnormalities in the Finnish National Gallery

Kluger, Nicolas

2020-04

Kluger , N 2020 , ' Skin abnormalities in the Finnish National Gallery ' , Journal of Cosmetic Dermatology , vol. 19 , no. 4 , pp. 960-963 . https://doi.org/10.1111/jocd.13095

http://hdl.handle.net/10138/319416

https://doi.org/10.1111/jocd.13095

unspecified

publishedVersion

Downloaded from Helda, University of Helsinki institutional repository.

This is an electronic reprint of the original article.

This reprint may differ from the original in pagination and typographic detail.

Please cite the original version. 


\title{
Skin abnormalities in the Finnish National Gallery
}

\author{
Nicolas Kluger $\mathrm{MD}, \mathrm{PhD}^{1,2}$
}

${ }^{1}$ Department of Dermatology, Allergology and Venereology, Helsinki University Central Hospital, Helsinki, Finland

${ }^{2}$ Société Française des Sciences Humaines sur la Peau (SFSHP), Maison de la

Dermatologie, Paris, France

\section{Correspondence}

Nicolas Kluger, Department of Dermatology, Skin and Allergy Hospital, Helsinki

University Central Hospital, Helsinki,

Finland.

Email: nicolas.kluger@hus.fi

\begin{abstract}
The search for clinical signs suggestive of diseases and medical analysis in works of art and portraits is also known as iconodiagnosis. It raises discussions about underlying diseases and about whether the artist intended to represent them. We assessed the frequency of cutaneous signs in paintings on display in the permanent collections of the Ateneum and Sinebrychoff Art Museums, Finnish National Gallery in Helsinki. The most common feature was facial redness. Redness was mainly located on the cheeks with variable intensity according to paintings. Facial redness may be related to stylistic features, to make-up of the sitter, or the painter intended to depict an individual in good health or a specific emotion. It may be also related to rosacea, a common feature in individuals with fair skin. Lupus was not evoked in any of the cases. Additional specific findings included mainly sun-exposed skin lesions such as sun tan or chronic poikiloderma, skin aging (Milian's citrine skin), naevi, keratosis pilaris rubra, and ear piercing. We report here some specificities of the skin conditions displayed in the Finnish National Gallery. Examining from a dermatological point of view, works of art gives to a museum visit a twist.
\end{abstract}

KEYWORDS

facial redness, iconodiagnosis, painting, rosacea, skin disease

\section{1 | INTRODUCTION}

The search for clinical signs suggestive of diseases and medical analysis in works of art and portraits (also known as iconodiagnosis ${ }^{1,2}$ ) is an enjoyable exercise. It raises discussions about underlying diseases and about whether the artist intended to represent them. ${ }^{3,4}$ Analysis of the skin of the sitters or depicted characters provides a perfect example of such exercise. ${ }^{5,6}$ On the other hand, subjective interpretation by the physician of the painter's interpretation of the models' appearance is unavoidable. ${ }^{7}$ Besides, unilateral analysis without putting work of art in their proper artistic and historical context exposes to erroneous explanations. ${ }^{8-10}$

Acknowledging that, we followed the steps of Strauss et $\mathrm{al}^{7}$ and assessed the frequency of cutaneous signs reflected in paintings on display at Ateneum and Sinebrychoff Art Museums, Finnish National Gallery in Helsinki. The Ateneum's permanent collection covers the period between the 19th and the end of the 20th century by mostly

All the used images of this work are released under a CCO license and can be freely use.
Finnish artists while Sinebrychoff's collection gathers paintings by old European masters, 14th up to the mid-19th century.

\section{2 | METHODS}

We performed a review of all canvasses that included human subjects on display on December 29, 2018 (Ateneum) and January 2, 2019 (Sinebrychoff). We screened paintings concentrating on face, hands, and all exposed skin as formerly reported. ${ }^{7}$ A total of 283 paintings were examined in Ateneum, including 73 artists' portraits and self-portraits from the public portrait collection and 114 portraits in Sinebrychoff.

\section{3 | RESULTS}

The commonest findings were features of redness of the cheek and nose, evocative of rosacea in 46 paintings in Ateneum and in 73 paintings (64\% of the collection) in Sinebrychoff (Figure 1). The 
${ }^{2}{ }_{\text {WILEY }}-\underset{\substack{\text { coumente } \\ \text { Cosmelic Dematology }}}{\mathrm{ICD}}$

FIGURE 1 Examples of skin conditions observed in portraits in Ateneum and Sinebrychoff Art Museums. A, Dermal nevus or seborrheic keratosis of the left upper lid. Gustaf Lundberg (1695-1786): Mary Ulrika Dahl (year?), Finnish National Gallery/Sinebrychoff Art Museum/ photography Hannu Aaltonen. B, Facial erythema in the cold. Robert W. Ekman (1808-1873): Beggar family on the road (1860) (Detail), Finnish National Gallery/Ateneum Art Museum/photography Hannu Aaltonen. C, Intense facial erythema. Carl Fredrik von Breda (1759-1818): Beata Charlotta Gripenwaldt, née Wennerstedt (1811), Finnish National Gallery/Sinebrychoff Art Museum/photography Henri Tuomi and Hannu Pakarinen. D, Facial erythema of the cheeks. Maria Wiik (1853-1928): Elsa (1882), Finnish National Gallery/Ateneum Art Museum/photography Pirje Myykänen. E, Sun tan of the upper arms. Beda Stjernschantz (1867-1910): Girl sitting (1892), Finnish National Gallery/Ateneum Art Museum/photography Hannu Aaltonen. F, Milian citrin's skin and Favre et Racouchot's disease. Hugo Simberg (1873-1917): Auntie; The Artist's Aunt (1898), Finnish National Gallery/Ateneum Art Museum/photography Kari Soinio. G, Rosacea and smoking. Vilho Lampi (1898-1936): Self-Portrait (1933), Finnish National Gallery/Ateneum Art Museum/photography Janne Tuominen. H, Ear cyst. Albert Edelfelt (1854-1905): Conveying the Child's Coffin (A Child's Funeral) (1879), Finnish National Gallery/Ateneum Art Museum/ photography Hannu Aaltonen. I, Sun tan of the face and neck. Possible poikiloderma. Akseli Gallen-Kallela (1865-1931): By the river of Tuonela, study for the Jusélius Mausoleum frescos (1903), Finnish National Gallery/Ateneum Art Museum/photography Jukka Romu

redness intensity was highly variable according to painters and style, from discrete redness of the cheeks (E. Löfgren, 1864, Erik XIV and Karin Månsdotter) to dark red features (CF von Breda, Beata Charlotta Gripenwaldt, 1811; M. Wiik, Elsa 1882). Interestingly in 3 cases, facial redness was associated with active smoking and objects suggesting alcohol consumption around the portraited (Figure 1E). Eighteen out of the 73 artists' portraits (so almost one out of four) in Ateneum Art Museum showed signs of moderate or marked facial erythema evocative of rosacea. In a painting by Dutch portraitist Johannes Cornelisz Versponck, we considered a diagnosis of keratosis pilaris rubra of the face as highly possible. ${ }^{11}$ Ear lobe piercing was observed in 9 portraits of women at Sinebrychoff's. Other dermatological findings are summarized in Table 1. The most striking painting from the permanent collection is Auntie by
TABLE 1 Dermatological conditions found in the screened portraits (excluding rosacea)

\begin{tabular}{|c|c|c|c|}
\hline Artist & Painting & Subject & Possible pathology \\
\hline \multicolumn{4}{|c|}{ Sinebrychoff Art Museum } \\
\hline Gustaf Lundberg & $\begin{array}{l}\text { Maria Ulrika Dahl, } \\
\text { undated }\end{array}$ & $\begin{array}{l}\text { Maria Ulrika } \\
\text { Dahl }\end{array}$ & $\begin{array}{l}\text { Dermal nevus of the left } \\
\text { upper eyelid }\end{array}$ \\
\hline Georg Desmarée & Portrait of a man & Unknown man & Wig with white forelock \\
\hline Jan Verspronck & $\begin{array}{l}\text { Anna van } \\
\text { Schoonhoven, } 1675\end{array}$ & $\begin{array}{l}\text { Anna van } \\
\text { Schoonhoven }\end{array}$ & Keratosis pilaris rubra ${ }^{11}$ \\
\hline \multicolumn{4}{|c|}{ Ateneum Art Museum } \\
\hline $\begin{array}{l}\text { Aleksi } \\
\text { Gallen-Kallela }\end{array}$ & $\begin{array}{l}\text { By the River of } \\
\text { Tuonela (study } \\
\text { for the Jusélius } \\
\text { Mausoleum fres- } \\
\text { cos), } 1860\end{array}$ & Unknown man & $\begin{array}{l}\text { Facial chronic sun expo- } \\
\text { sure (red neck, Civatte } \\
\text { poikiloderma) }\end{array}$ \\
\hline Albert Edelfelt & $\begin{array}{l}\text { Conveying the } \\
\text { Child's Coffin, } 1879\end{array}$ & The mother & Cyst of the right auricle \\
\hline $\begin{array}{l}\text { Beda } \\
\text { Stjernschantz }\end{array}$ & Girl sitting, 1892 & Unknown girl & Sun tan of the forearm \\
\hline Hugo Simberg & Auntie, 1898 & Painter's aunt & $\begin{array}{l}\text { Skin aging: Milian's citrin } \\
\text { skin, }\end{array}$ \\
\hline Edvard Munch & $\begin{array}{l}\text { Bathing Men, } \\
\text { 1907-1908 }\end{array}$ & Unknown men & $\begin{array}{l}\text { Sun tan of the face and } \\
\text { upper arms/hands }\end{array}$ \\
\hline Antti Favén & $\begin{array}{l}\text { The Artist Fahle } \\
\text { Basilier, } 1908\end{array}$ & Fahle Basilier* & $\begin{array}{l}\text { Dermal nevus } \\
\text { Melanocytic nevus }\end{array}$ \\
\hline Antti Favén & $\begin{array}{l}\text { Portrait of Eino } \\
\text { Leino, } 1922\end{array}$ & Eino Leino** & $\begin{array}{l}\text { Dermatoporosis of the } \\
\text { forearm }\end{array}$ \\
\hline Martti Ranttila & Selling a watch, 1933 & Unknown man & $\begin{array}{l}\text { Venous dilatation of the } \\
\text { hand }\end{array}$ \\
\hline Paavo Leinonen & Self-portrait, 1933 & $\begin{array}{l}\text { The artist } \\
\text { himself }\end{array}$ & Facial erythrosis \\
\hline $\begin{array}{l}\text { Ernst Mether- } \\
\text { Borgström }\end{array}$ & $\begin{array}{l}\text { Self-portrait with a } \\
\text { Yellow Flower in the } \\
\text { Hand, } 1943\end{array}$ & $\begin{array}{l}\text { The artist } \\
\text { himself }\end{array}$ & Protruding ears \\
\hline
\end{tabular}

*Finnish painter (1880-1936).

**Finnish poet (1878-1926). 
symbolist painter Hugo Simberg (1898). He depicted with precision facial skin aging with thickened yellowish-white skin and wrinkles of the temporal areas. Favre and Raccouchot's dilated pores and comedones were not represented here though (Figure 1D).

\section{4 | DISCUSSION}

We found very few notable skin modifications among portraits in the Sinebrychoff Art Museum especially. The museum includes a high number of public portraits, which could explain that painters may have embellished the sitter's portrait. The frequency of facial redness was here striking, when compared to the results found by Strauss et al in the National Portrait Gallery in London. ${ }^{7}$ Redness of the cheeks is stylistic features. They can be used to emphasize the cheeks, related to make-up to give more life to a portrait or to depict a healthy child or adult (Helene Schjerfbeck, A Boy feeding his little sister, 1881; The Convalescent, 1888) or to depict emotion such as shame, lust, or embarrassment. Redness can illustrate the harshness of cold environment (Robert W Ekman, Beggar family on the road, 1860). A butterfly malar rash related to lupus has been sometimes been mentioned by other authors in various paintings. ${ }^{12-15}$ However, without the knowledge of the health of the portraited and additional evocative signs, we did not consider this diagnosis in any of our paintings. We may have been more sensitive by including all the redness, even the less visible ones, while Strauss et al may also have taken into account only the striking cases of facial redness. $^{7}$

Finnish art is rather young as it started in the 1800s after Finland has been handed to Russia. ${ }^{16}$ Starting from the mid-nineteenth century, Finnish artists shifted to a more realistic expression. ${ }^{16}$ It may therefore indirectly show the high frequency of rosacea among Finns. We think that there was no attempt by Finnish artists to hide reality, even though it is always possible that the artist may have lessen physical defects, in public figures especially as previously discussed. ${ }^{7}$ Limitations of our study include the aforementioned individual interpretation by the author and, on a technical point of view, difficulties to perform a correct analysis of the paintings due to room lightning in the museums. One can also discuss the possibility of fake diagnosis due, not to a real disease, but a slight talent of the painter.

We report here some specificities of the skin conditions as displayed in the Finnish National Gallery. Examining from a dermatological point of view, works of art gives a museum visit a new twist.

\section{CONFLICT OF INTEREST}

None declared.

\section{ORCID}

Nicolas Kluger (iD https://orcid.org/0000-0002-5225-8316

\section{REFERENCES}

1. Pontius AA. Icono-diagnosis, a medical-humanistic approach, detecting Crouzon's malformation in Cook Islands' prehistoric art. Perspect Biol Med. 1983;27:107-120.

2. Charlier P. A new case of facial paralysis on a terra cotta Hellenistic smyrniote. Icono-diagnosis and paleopathology of facial paralyses. Hist Sci Med. 2007;41:49-60.

3. Als C, Stüssi Y, Boschung U, Tröhler U, Wäber JH. Visible signs of illness from the 14th to the 20th century: systematic review of portraits. BMJ. 2002;325:1499.

4. Sharma P. Medicine, Dürer, and the praying hands. Lancet. 1997;349:1470-1471.

5. Om A, Om A. Integrating the integumentary system with the arts: a review of dermatologic findings in artwork. J Clin Aesthet Dermatol. 2018;11:21-27.

6. Ashrafian H. Earliest depiction of vitiligo in "Venus at a Mirror" (1615) by Peter Paul Rubens (1577-1640). J Cosmet Dermatol. 2018;17:566-567.

7. Strauss RM, Marzo-Ortega H, Goulden V. Skin abnormalities in the National Portrait Gallery. J Eur Acad Dermatol Venereol. 2004;18:566-568.

8. Fernandez-Flores A. Frontal pseudoalopecia in history: part 1Fashionable forms. Clin Dermatol. 2012;30:548-552.

9. Vein AA, Mouret A. Claw hand in a renaissance portrait. Lancet Neurol. 2018;17:742.

10. Charlier P, Lippi D, Perciaccante A, Appenzeller O, Bianucci R. Neurological disorder? No, Mannerism. Lancet Neurol. 2019;18:135.

11. Kluger N. A case of keratosis pilaris rubra in a 17 th century portrait? J Eur Acad Dermatol Venereol. 2019;33:1450-1451.

12. Marson $\mathrm{P}$, Rondinone R, Vicarioto $\mathrm{M}$. Malar rash in a painting by Jean-Baptiste Siméon Chardin (1699-1779). Reumatismo. 2001;53(2):175-179.

13. Hayakawa S, Komine-Aizawa S, Osaka S, et al. Rembrandt's Maria Bockenolle has a butterfly rash and digital deformities: overlapping syndrome of rheumatoid arthritis and systemic lupus erythematosus. Med Hypotheses. 2007;68:906-909.

14. Ashrafian H. Catherine of Aragon (1485-1536): the red malar rash of familial SLE in a Tudor red rose queen. Rheumatol Int. 2015;35:1949-1950.

15. da Mota LM, Neubarth F, de Carvalho JF, Diniz LR, Aires RB, Dos Santos-Neto LL. Adele Bloch-Bauer (1881-1925): possible diagnoses for Gustav Klimt's Lady in Gold. J Med Biogr. 2016;24:389-396.

16. Susanna P. Stories of Finnish Art. Berlin, Germany: Hatje Cantz Verlag; 2016:264.

How to cite this article: Kluger N. Skin abnormalities in the Finnish National Gallery. J Cosmet Dermatol. 2019;00:1-4. https://doi.org/10.1111/jocd.13095 